\title{
PENGARUH MODEL INKUIRI TERBIMBING BERBASIS LINGKUNGAN TERHADAP KEMAMPUAN PEMAHAMAN KONSEP DAN KARAKTER
}

\author{
Novi Yuliyanti ${ }^{1)}$ \\ noviyuliyanti61@gmail.com \\ Universitas Majalengka
}

\begin{abstract}
ABSTRAK
Penelitian ini bertujuan untuk: 1) mengetahui pengaruh model pembelajaran inkuiri terbimbing berbasis lingkungan terhadap pemahaman konsep, 2) mengetahui pengaruh model pembelajaran inkuiri terbimbing berbasis lingkungan terhadap karakter, 3) mengetahui pengaruh model pembelajaran inkuiri terbimbing berbasis lingkungan terhadap karakter dan pemahaman konsep. Desain penelitian menggunakan True experimental design dengan bentuk design pretest-posttest control group design. Populasi dari penelitian ini adalah seluruh siswa kelas V SD seKecamatan Brebes Kota Kabupaten Brebes 2014/2015. Teknik pengambilan sampel menggunakan purposive sampling. Sampel pada penelitian ini berjumlah 206 siswa dengan rincian 101 siswa sebagai kelompok eksperimen dan 105 siswa sebagai kelompok kontrol. Teknik pengumpulan data yang digunakan adalah tes pemahaman konsep IPA dan angket karakter siswa. Uji normalitas menggunakan metode Lilliefors, uji homogenitas menggunakan metode Bartlett, uji hipotesis menggunakan regresi linear sederhana dan analisis varians dua jalur pada taraf signifikansi $\alpha=0.05$. Hasil penelitian menunjukkan bahwa, 1) terdapat pengaruh model pembelajaran inkuiri terbimbing berbasis lingkungan terhadap pemahaman konsep sebesar $15 \%, 2$ ) terdapat pengaruh model pembelajaran inkuiri terbimbing berbasis lingkungan terhadap karakter sebesar $12,2 \%, 3)$ terdapat pengaruh model pembelajaran inkuiri terbimbing berbasis lingkungan terhadap pemahaman konsep dan karakter sebesar 95,2\%. Berdasarkan pada hasil penelitian, maka dapat disimpulkan bahwa 1) terdapat pengaruh model pembelajaran inkuiri terbimbing berbasis lingkungan terhadap pemahaman konsep, 2) terdapat pengaruh model pembelajaran inkuiri terbimbing berbasis lingkungan terhadap karakter, 3) terdapat pengaruh model pembelajaran inkuiri terbimbing berbasis lingkungan terhadap pemahaman konsep dan karakter.
\end{abstract}

Kata Kunci: Inkuiri Terbimbing, Pemahaman Konsep, Karakter.

\footnotetext{
${ }^{1}$ Penulis adalah dosen tetap Prodi PGSD Fakultas Pendidikan Dasar dan Menengah Universitas Majalengka
} 


\section{Pendahuluan}

Sekolah sebagai lembaga formal dalam mencetak generasi bangsa yang tangguh dan mampu berkompetisi harus selalu berinovasi dalam memberikan pembelajaran yang bermakna bagi siswanya. Salah satunya adalah dengan menerapkan model pembelajaran inkuiri terbimbing berbasis lingkungan. Model pembelajaran inkuiri terbimbing berbasis lingkungan menekankan pada pemberian pengalaman secara langsung untuk mengembangkan kompetensi agar siswa mampu menjelajahi dan memahami alam sekitar secara ilmiah. Pengalaman belajar diperoleh melalui serangkaian kegiatan untuk mengeksplorasi lingkungan melalui interaksi aktif dengan teman, lingkungan dan sumber lain.

Winnie (2014) menyatakan bahwa model pembelajaran inkuiri terbimbing dapat meningkatkan kemampuan memahami konsep melalui kegiatan mengamati, mengumpulkan data, menganalisis data, mensintesis data sampai pada penarikan kesimpulan. Pendidikan IPA diarahkan untuk mencari tahu dan berbuat, sehingga bisa membantu siswa memperoleh pemahaman yang lebih mendalam tentang alam sekitar (Putra, 2013:40). Proses pembelajaran IPA yang bermakna diharapkan mampu meningkatkan kualitas pendidikan di Indonesia.

Kualitas pendidikan yang bermutu akan menghasilkan SDM yang mampu berkompetisi dan berkarakter. Pembentukan karakter erat kaitannya dengan implementasi pembelajaran IPA. Damayanti (2014:10) pembentukan karakter adalah upaya untuk membantu perkembangan jiwa anak baik lahir maupun batin dari sifat kodratinya menuju ke arah peradaban masyarakat dan bangsa secara umum.

Berdasarkan hasil wawancara dengan guru kelas $\mathrm{V}$ secara langsung di SD Negeri Se-Kecamatan Brebes Kota diperoleh informasi bahwa: 1) pemahaman konsep IPA pada siswa masih rendah, 2) pembelajaran masih bersifat teacher center dan perlu adanya peningkatan, 3) belum melibatkan siswa selama proses pembelajaran, 4) perlu menerapkan karakter di setiap proses pembelajaran.

Rendahnya pemahaman konsep siswa diperkuat dengan data perolehan nilai yang ada di lapangan pada siswa kelas $\mathrm{V}$ yang belum memenuhi harapan. Dari data perolehan nilai Ujian Semester Ganjil siswa pada tahun 2014, sebagian nilai siswa masih di bawah KKM (Kriteria Ketuntasan Minimal). Dari tiga SD responden diperoleh data bahwa terdapat $37,2 \%$ - $62,8 \%$ nilai siswa yang masih berada di bawah KKM. Rendahnya nilai siswa disebabkan kurangnya kemampuan siswa dalam memahami konsep materi pelajaran.

Oleh karena itu, peneliti mengadakan penelitian tentang pengaruh model pembelajaran inkuiri terbimbing berbasis lingkungan terhadap kemampuan pemahaman konsep dan karakter pada siswa kelas V SD. Penelitian ini bertujuan untuk: 1) mengetahui pengaruh model pembelajaran inkuiri terbimbing berbasis lingkungan terhadap pemahaman konsep, 2) mengetahui pengaruh model pembelajaran inkuiri terbimbing berbasis lingkungan terhadap karakter, 3) mengetahui pengaruh model pembelajaran inkuiri terbimbing berbasis lingkungan terhadap karakter dan pemahaman konsep.

\section{Pemahaman Konsep}

Pada umumnya, pemahaman mendapat penekanan dalam proses belajar mengajar. Sanjaya berpendapat, pemahaman (understanding) yaitu kedalaman pengetahuan yang dimiliki setiap individu (2006:70). Winkel berpendapat, pemahaman mencakup kemampuan untuk menangkap arti dan makna dari bahan materi yang dipelajari (2004:274). 
Jacobsen, Eggen, dan Kauchak menyatakan bahwa pemahaman melibatkan proses-proses yang banyak menuntut pemikiran (thought demanding processes), seperti menjelaskan, menemukan, memberikan alasan, memberi contoh dan saling menghubungkan dengan semua bagian yang ada (2009:229).

Menurut Anderson dan Krathwohl (2001:54) menegaskan bahwa kategori kognitif understanding dibagi menjadi tujuh, yaitu:

1) Menafsirkan (interpretting)

2) Memberikan contoh (exemplifying)

3) Mengklasifikasikan (classifying)

4) Meringkas (summarising)

5) Menarik inferensi (inferring)

6) Membandingkan (comparing)

7) Menjelaskan (explaning)

Menurut Sudjana (2009:24), untuk dapat memahami kita perlu mengenal atau mengetahuinya terlebih dahulu. Sudjana membagi pemahaman ke dalam tiga kategori, yaitu:

1) Pemahaman tingkat rendah adalah pemahaman terjemahan yang dimulai dari terjemahan dalam arti yang sebenarnya, misalnya dari bahasa Inggris ke dalam bahasa Indonesia.

2) Pemahaman tingkat kedua adalah pemahaman penafsiran, yaitu menghubungkan bagian-bagian yang terdahulu dengan yang diketahui berikutnya atau menghubungkan grafik dengan sebuah peristiwa.

3) Pemahaman tingkat ketiga atau tingkat tertinggi adalah pemahaman ekstraplorasi. Dengan ekstraplorasi diharapkan seseorang mampu melihat di balik yang tertulis, dapat memperluas persepsi dalam arti waktu, permasalahan ataupun sebuah kasus.

Dari beberapa pendapat di atas, dapat disimpulkan bahwa pemahaman adalah proses mengetahui atau menangkap arti dari sebuah kejadian, masalah, kasus atau sesuatu yang kita pelajari.

Hasil utama dari pendidikan adalah belajar tentang konsep. Untuk memecahkan masalah, seorang siswa harus mengetahui aturan-aturan yang relevan dan aturan yang berdasarkan pada konsep yang ia peroleh. Dahar berpendapat, konsep merupakan dasar bagi proses mental yang lebih tinggi guna merumuskan prinsip dan generalisasi (2002: 62). Menurut Rosser (dalam Dahar, 2002:63), konsep adalah suatu abstraksi yang mewakili satu kelas objek, kegiatan, kejadian, atau hubungan yang mempunyai atribut sama. Usman Samatowa berpendapat bahwa konsep merupakan abstraksi yang didasarkan pada pengalaman (2010:52).

Hamalik berpendapat, konsep adalah suatu kelas stimuli yang memiliki sifat-sifat (atribut-atribut) yang umum (2010:161). Stimuli yang dimaksud adalah objek-objek atau orang. Ciri-ciri konsep menurut Hamalik (2010:162) yaitu:

1) Atribut konsep adalah sifat yang membedakan antara konsep satu dengan konsep lainnya.

2) Atribut nilai-nilai, adanya variasi-variasi yang terdapat pada suatu atribut.

3) Jumlah atribut juga bermacam-macam antara satu konsep dengan konsep lainnya.

4) Kedominanan atribut, menunjuk pada kenyataan bahwa beberapa atribut lebih dominan (obvius) daripada yang lainnya.

\section{Karakter}

Pendidikan adalah usaha sadar dan terencana dalam mewujudkan suasana belajar dan proses pembelajaran yang kondusif agar peserta didik aktif mengembangkan potensi yang dimilikinya untuk menjadi manusia yang beragama, mandiri, bertanggung jawab, kreatif, cerdas, berilmu, sehat, berakhlak atau berkarakter mulia dan mempunyai keterampilan yang diperlukan dirinya, masyarakat, bangsa dan 
negara (UU Sisdiknas No. 20 Tahun 2003). Karakter merupakan nilai-nilai universal perilaku manusia yang meliputi seluruh aktivitas kehidupan, baik yang berhubungan dengan Tuhan, diri sendiri dan sesama manusia maupun dengan lingkungan yang terwujud dalam pikiran, sikap, perasaan, perkataan dan perbuatan yang berdasarkan norma agama, hukum, tata krama, budaya dan adat istiadat (Suyadi, 2013:5).

Dari pengertian pendidikan dan karakter di atas, muncullah pendidikan karakter. Suyadi (2013:6) menyatakan bahwa pendidikan karakter adalah usaha sadar dan terencana dalam mengetahui kebenaran atau kebaikan, mencintainya kemudian menerapkannya dalam kehidupan sehari-hari. Penanaman karakter dilakukan melalui tahap pengetahuan yang dilanjutkan dengan tindakan dan menjadi kebiasaan. Pendidikan karakter memuat nilai-nilai yang perlu ditanamkan, ditumbuhkan dan dikembangkan kepada setiap peserta didik. Nilai-nilai yang dikembangkan tersebut tidak lepas dari budaya Bangsa Indonesia.

Tujuan pendidikan karakter adalah menanamkan nilai dalam diri siswa agar kehidupannya tertata sesuai dengan norma yang ada dalam masyarakat. Kementerian Pendidikan Nasional (2010:9), tujuan pendidikan karakter yang diharapkan adalah:

1. Mengembangkan potensi kalbu/nurani/afektif peserta didik sebagai manusia dan warganegara yang memiliki nilai-nilai budaya dan karakter bangsa.

2. Mengembangkan kebiasaan dan perilaku peserta didik yang terpuji dan sejalan dengan nilai-nilai universal dan tradisi budaya bangsa yang religius.

3. Menanamkan jiwa kepemimpinan dan tanggung jawab peserta didik sebagai generasi penerus bangsa.

4. Mengembangkan kemampuan peserta didik menjadi manusia yang mandiri, kreatif dan berwawasan kebangsaan.
5. Mengembangkan lingkungan kehidupan sekolah sebagai lingkungan belajar yang aman, jujur, penuh kreativitas dan persahabatan serta dengan rasa kebangsaan yang tinggi dan penuh kekuatan (dignity).

Menurut Lickona dalam (Damayanti, 2014:14), terdapat tiga komponen dalam membentuk karakter yang baik pada diri peserta didik, yaitu: 1) moral knowing atau pengetahuan tentang moral, moral feeling atau perasaan tentang moral dan moral action atau perbuatan bermoral. Moral knowing merupakan bagian dalam dari ranah kognitif seseorang dan moral feeling merupakan aspek emosi yang harus mampu dirasakan oleh seseorang untuk menjadi manusia berkarakter. Sedangkan moral action merupakan perbuatan atau tindakan moral dari dua komponen karakter lainnya. Sehingga dalam penanaman karakter bisa dilakukan melalui tahap pengetahuan yang dilanjutkan dengan tindakan dan menjadi kebiasaan.

\section{Inkuiri terbimbing}

Sebelum melaksanakan kegiatan belajar mengajar, hendaknya seorang guru menentukan model pembelajaran terlebih dahulu agar kegiatan belajar mengajar bisa berjalan dengan baik dan sesuai dengan tujuan yang diinginkan. Anitah berpendapat, model adalah suatu kerangka berpikir yang dipakai sebagai panduan untuk melaksanakan kegiatan dalam rangka mencapai tujuan tertentu (2009:45). Sagala berpendapat, model diartikan sebagai kerangka konseptual yang digunakan sebagai pedoman dalam melakukan kegiatan (2012:175). Merujuk pemikiran Joyce dalam (Suprijono, 2012:46) fungsi model adalah "each model guides us as we design instruction to help students achieve various objectives", yang artinya tiap model membimbing kita seperti kita mendesain 
instruksi untuk siswa sehingga dapat mencapai berbagai tujuan.

Aunurrahman berpendapat, model pembelajaran dapat diartikan sebagai kerangka konseptual yang melukiskan prosedur yang sistematis dalam mengorganisasikan pengalaman belajar untuk tujuan belajar tertentu, dan berfungsi sebagai pedoman bagi para perancang pembelajaran dan para guru untuk merencanakan dan melaksanakan aktivitas pembelajaran (2009:146). Suprijono berpendapat, model pembelajaran ialah pola yang digunakan sebagai pedoman dalam merencanakan pembelajaran di kelas maupun tutorial (2012:46).

Sedangkan Trianto berpendapat bahwa model pembelajaran adalah suatu perencanaan atau suatu pola yang digunakan sebagai pedoman dalam merencanakan pembelajaran di kelas atau pembelajaran dalam tutorial dan untuk menentukan perangkat-perangkat pembelajaran termasuk di dalamnya buku-buku, film , komputer, kurikulum, dan lain-lain (2009:22). Stalling (1997) dalam (Aunurrahman, 2010:147) mengemukakan 5 model dalam pembelajaran:

1) The Exploratory Model. Model ini pada dasarnya bertujuan untuk mengembangkan kreativitas dan independensi siswa.

2) The Group Process Model. Model ini utamanya diarahkan untuk mengembangkan kesadaran diri, rasa tanggung jawab, dan kemampuan bekerjasama antar siswa.

3) The Developmental Kognitive Model, yang menitikberatkan untuk mengembangkan keterampilanketerampilan kognitif.

4) The Programmed Model, yang dititikberatkan untuk mengembangkan keterampilan-keterampilan dasar melalui modifikasi tingkah laku.
5) The Fundamental Model, yang dititikberatkan untuk mengembangkan keterampilan-keterampilan dasar melalui pengetahuan faktual.

Menurut Hamdani (2011:180) ada lima kriteria yang dapat dipakai sebagai pedoman dalam memilih model pembelajaran, yaitu:

1) Sederhana, bentuk sederhana akan mempermudah siswa untuk mengerti, mengikuti, dan menggunakannya.

2) Lengkap, suatu model pembelajaran yang lengkap haruslah mengandung tiga unsur pokok, yaitu identifikasi, pengembangan, dan evaluasi.

3) Mungkin diterapkan, artinya model yang dipilih hendaklah dapat diterima dan diterapkan (applicable), sesuai dengan situasi dan kondisi setempat.

4) Luas, jangkauan model tersebut hendaklah cukup luas, tidak saja berlaku untuk pola belajar mengajar yang konvensional, tetapi juga proses belajar mengajar yang lebih luas, baik yang menghendaki kehadiran guru secara fisik maupun yang tidak.

5) Teruji, model yang bersangkutan telah dipakai secara luas dan teruji atau terbukti dapat memberikan hasil yang baik.

Dari beberapa pendapat di atas, dapat disimpulkan bahwa model pembelajaran merupakan unsur yang penting untuk menjalankan kegiatan belajar siswa di sekolah karena dengan menerapkan model pembelajaran yang baik pada siswa, akan mempermudah guru dalam mengajar dan menjadikan proses belajar yang baik dan menarik pada diri siswa. Melalui model pembelajaran guru dapat membantu siswa dalam menemukan informasi, keterampilan, cara berpikir, mengekspresikan ide, berinteraksi, bertanggung jawab dan melatih keberanian siswa.

Pembelajaran inkuiri terbimbing adalah suatu strategi yang membutuhkan siswa menemukan sesuatu dan mengetahui 
bagaimana cara memecahkan masalah dalam suatu penelitian ilmiah (Ngalimun, 2014:33). Inkuiri terbimbing merupakan suatu proses untuk memperoleh informasi melalui observasi atau eksperimen untuk memecahkan suatu masalah dengan menggunakan kemampuan berpikir kritis dan logis dengan bimbingan guru (Putra, 2013:86-87). Tujuan utamanya adalah mengembangkan sikap dari keterampilan siswa yang memungkinkan mereka menjadi pemecah masalah yang mandiri. Model pembelajaran inkuiri terbimbing merupakan model pembelajaran yang berpusat pada peserta didik (student center). Chen \& She (2013) menganggap inkuiri merupakan strategi yang penting dan efisien dalam pembelajaran IPA. Banyak penelitian yang menunjukkan bahwa inkuiri dapat mendorong penalaran ilmiah siswa sebagai salah satu tujuan pendidikan.

Model pembelajaran inkuiri terbimbing adalah model pembelajaran dimana guru membimbing siswa melakukan kegiatan dengan memberi pertanyaan awal dan mengarahkan pada suatu diskusi (Jauhar, 2011:67). Guru mempunyai peran aktif dalam menentukan permasalahan dan tahap-tahap pemecahannya. Model pembelajaran inkuiri terbimbing diperuntukkan bagi siswa sekolah dasar yang masih dalam tahap dibimbing selama proses belajar. Pada dasarnya, siswa selama proses belajar berlangsung akan memperoleh pedoman sesuai yang dibutuhkan. Pada tahap awal, guru akan memberikan banyak bimbingan, kemudian pada tahapan berikutnya guru akan mengurangi bimbingan tersebut, sehingga siswa mampu melakukan proses inkuiri secara mandiri. Bimbingan yang diberikan guru dapat berupa pertanyaan-pertanyaan dan diskusi multi arah yang dapat menggiring siswa agar dapat memahami konsep pelajaran IPA. Di samping itu, bimbingan dapat pula diberikan melalui lembar kerja siswa yang terstruktur.
Selama berlangsungnya proses belajar guru harus memantau kelompok diskusi siswa, sehingga guru dapat mengetahui petunjukpetunjuk dan scaffolding yang diperlukan oleh siswa.

Menurut Memes (dalam Jauhar, 2011:85), ada enam langkah yang harus diperhatikan dalam pembelajaran inkuiri terbimbing, yaitu:

1. Merumuskan masalah.

2. Membuat hipotesis.

3. Merencanakan kegiatan.

4. Melaksanakan kegiatan.

5. Mengumpulkan data.

6. Mengambil kesimpulan.

Siswa akan berperan aktif melatih keberanian, berkomunikasi dan berusaha mendapatkan pengetahuannya sendiri untuk memecahkan masalah yang dihadapi. Tugas guru adalah mempersiapkan skenario pembelajaran sehingga pembelajarannya dapat berjalan dengan lancar.

Menurut Gulo (dalam Jauhar, 2011:84-85), peranan utama guru dalam menciptakan kondisi pembelajaran inkuiri terbimbing adalah sebagai berikut:

1. Guru sebagai motivator yang memberikan rangsangan supaya siswa aktif dan bersemangat dalam berpikir.

2. Guru sebagai fasilitator yang menunjukkan jalan keluar jika ada hambatan dalam proses berpikir siswa.

3. Guru sebagai penanya, untuk menyadarkan siswa dari kekeliruan yang mereka perbuat dan memberikan keyakinan pada diri sendiri.

4. Guru sebagai administrator, yang bertanggung jawab terhadap seluruh kegiatan yang berada di dalam kelas.

5. Guru sebagai pengarah yang memimpin arus kegiatan berpikir siswa pada tujuan yang diharapkan.

6. Guru sebagai manajer yang mengelola sumber belajar, waktu dan organisasi kelas. 
7. Guru sebagai rewarder yang memberi penghargaan kepada siswa yang berprestasi dalam rangka peningkatan semangat heuristik.

Pembelajaran inkuiri ditekankan pada proses berpikir secara kritis dan analitis untuk mencari dan menemukan sendiri jawaban dari suatu masalah yang dipertanyakan. Ada beberapa hal yang menjadi ciri utama model pembelajaran inkuiri: 1) model pembelajaran menekankan pada aktivitas siswa secara maksimal untuk mencari dan menemukan, 2) seluruh aktivitas yang dilakukan siswa diarahkan untuk mencari dan menemukan sendiri dari sesuatu yang dipertanyakan, sehingga diharapkan dapat menumbuhkan sikap percaya diri (self belief), 3) mengembangkan kemampuan intelektual sebagai proses mental. Model pembelajaran inkuiri akan menghadapkan peserta didik pada beberapa masalah untuk dicari solusi penanganannya, sehingga nanti akan ditemukan sebuah temuan baru yang merupakan hasil dari pemecahan masalah yang dilakukan peserta didik.

\section{Metodologi}

Jenis penelitian ini adalah penelitian eksperimen. Penelitian eksperimen adalah metode penelitian yang digunakan untuk mencari pengaruh perlakuan tertentu terhadap yang lain dalam kondisi yang terkendalikan (Sugiyono, 2010:107). Penelitian eksperimen merupakan bagian dari penelitian kuantitatif yang mempunyai ciri khas tersendiri, terutama dengan adanya kelompok kontrol. Penelitian ini menggunakan True experimental design dengan bentuk design pretest-posttest control group design, dimana responden benar-benar dipilih secara random, kemudian diberi pretest untuk mengetahui keadaan awal antara kelompok eksperimen dan kelompok kontrol. Populasi dalam penelitian ini adalah seluruh siswa kelas V semester II SD Se-Kecamatan BrebesKota Kabupaten Brebes Tahun Ajaran 2014/2015 dengan perincian SD Negeri 2 Brebesn dengan jumlah siswa kelas VA 33 siswa dan kelas VB 35 siswa, SD Negeri 4 Brebes dengan jumlah siswa kelas VA 45 siswa dan kelas VB 44 siswa sedangkan SD IT dengan jumlah siswa kelas VB 25 siswa dan kelas VC 24 siswa. Teknik pengambilan sampel dalam penelitian ini dilakukan secara purposive sampling yaitu teknik penarikan sampel yang dilakukan untuk tujuan tertentu dengan melihat karakteristik tiap SD.

Teknik pengumpulan data yang digunakan dalam penelitian ini menggunakan dua instrumen, yaitu instrumen pembelajaran dan instrumen pengumpul data. Instrumen pembelajaran terdiri atas perangkat pembelajaran yang digunakan sebagai penunjang dalam pelaksanaan pembelajaran. Sedangkan instrumen pengumpul data merupakan perangkat yang digunakan untuk memperoleh data dan informasi proses belajar dan hasil belajar yang telah dilaksanakan. Teknik analisis data yang digunakan dalam penelitian ini adalah Uji normalitas menggunakan metode Lilliefors, uji homogenitas menggunakan metode Bartlett, uji hipotesis menggunakan regresi linear sederhana dan analisis varians dua jalur (Two Way Anova) pada taraf signifikansi $\alpha=0.05$.

\section{Hasil dan Pembahasan}

Data yang dideskripsikan dalam penelitian ini berupa data nilai pemahaman konsep siswa dan nilai karakter dengan menerapkan model pembelajaran inkuiri terbimbing berbasis lingkungan dan model pembelajaran langsung. Data pemahaman konsep diperoleh dari data nilai pretest dan posttest yang dirangkum pada Gambar 1: 


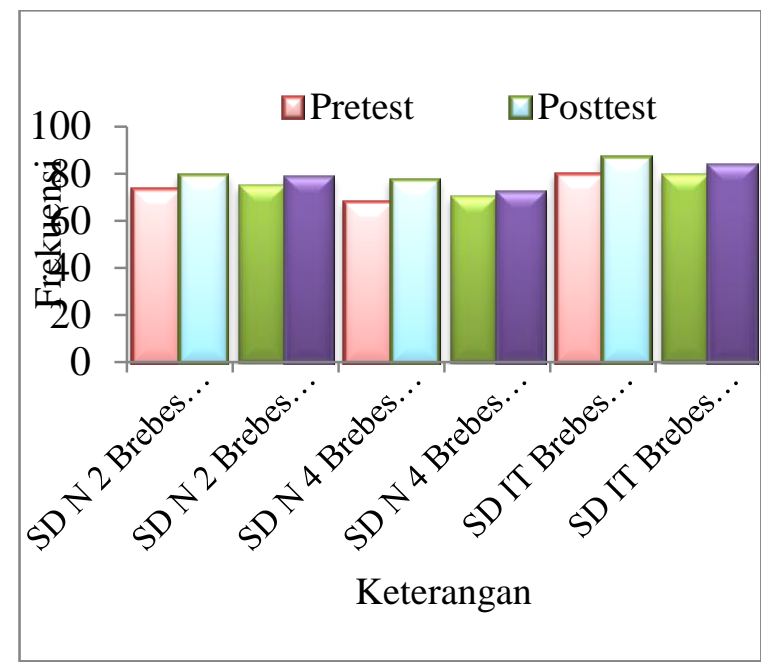

Karakter yang diteliti dalam penelitian ini adalah disiplin, rasa ingin tahu, kerja keras dan peduli lingkungan. Masingmasing karakter terdiri dari 10 pernyataan dengan skor maksimal 40. Data nilai karakter diperoleh dari nilai pretest dan nilai posttest.

Berdasarkan hasil analisis data diperoleh, 1) terdapat pengaruh model pembelajaran inkuiri terbimbing berbasis lingkungan terhadap pemahaman konsep berdasarkan uji regresi linear sederhana yaitu $\mathrm{Y}_{1}=7,883+0,783 \mathrm{X}$. Koefisien beta untuk variabel model pembelajaran inkuiri terbimbing berbasis lingkungan adalah 0,783 , sedangkan koefisien nilai t hitung dari koefisien tersebut adalah 4,176 dengan tingkat kesalahan 0,000 (yang lebih kecil dari 0,05). Dengan demikian, $\mathrm{H}_{0}$ ditolak dan $\mathrm{H}_{1}$ diterima. Penerimaan $\mathrm{H}_{1}$ menunjukkan bahwa model pembelajaran inkuiri terbimbing berbasis lingkungan berpengaruh terhadap pemahaman konsep. Koefisien determinasi model pembelajaran inkuiri terbimbing berbasis lingkungan dapat menjelaskan pemahaman konsep sebesar $15 \%$ dan sisanya $85 \%$ dijelaskan oleh faktor lain yang tidak diteliti. 2) terdapat pengaruh model pembelajaran inkuiri terbimbing berbasis lingkungan terhadap karakter berdasarkan uji regresi linear sederhana yaitu $\mathrm{Y}_{2}=239,849+(-1,093) \mathrm{X}$. Koefisien beta untuk variabel model pembelajaran inkuiri terbimbing berbasis lingkungan adalah -1,093, sedangkan koefisien nilai $\mathrm{t}$ hitung dari koefisien tersebut adalah -3,716 dengan tingkat kesalahan 0,000 (yang lebih kecil dari 0,05). Dengan demikian, $\mathrm{H}_{0}$ ditolak dan $\mathrm{H}_{1}$ diterima. Penerimaan $\mathrm{H}_{1}$ menunjukkan bahwa model pembelajaran inkuiri terbimbing berbasis lingkungan berpengaruh terhadap karakter. Koefisien determinasi model pembelajaran inkuiri terbimbing berbasis lingkungan dapat menjelaskan karakter sebesar $12,2 \%$ dan sisanya $87,8 \%$ dijelaskan oleh faktor lain yang tidak diteliti. 3) terdapat pengaruh model pembelajaran inkuiri terbimbing berbasis lingkungan terhadap pemahaman konsep dan karakter, dengan nilai $\mathrm{F}$ pada komponen pemahaman konsep dan karakter bernilai 2.646 yang signifikan pada tingkat kesalahan 0,031. Tingkat kesalahan tersebut lebih kecil daripada kesalahan yang ditentukan (0,05). Koefisien determinasi model pembelajaran inkuiri terbimbing berbasis lingkungan dapat menjelaskan pemahaman konsep dan karakter sebesar $95,2 \%$ dan sisanya $4,8 \%$ dijelaskan oleh faktor lain yang tidak diteliti.

Penelitian ini bertujuan untuk mengetahui pengaruh model pembelajaran inkuiri terbimbing berbasis lingkungan terhadap pemahaman konsep IPA materi daur air, pengaruh model pembelajaran inkuiri terbimbing berbasis lingkungan terhadap karakter dan pengaruh model pembelajaran inkuiri terbimbing berbasis lingkungan terhadap pemahaman konsep IPA materi daur air dan karakter.

a. Terdapat pengaruh model pembelajaran inkuiri terbimbing berbasis lingkungan terhadap pemahaman konsep. Koefisien determinasi model pembelajaran inkuiri terbimbing berbasis lingkungan dapat menjelaskan pemahaman konsep sebesar $15 \%$ dan sisanya $85 \%$ dijelaskan oleh faktor lain yang tidak diteliti. Hal ini 
diperkuat dengan pendapat Chen \& She (2013) yang menyatakan bahwa model pembelajaran inkuiri terbimbing efektif dan efisien untuk melaksanakan pembelajaran IPA.

b. Terdapat pengaruh model pembelajaran inkuiri terbimbing berbasis lingkungan terhadap karakter. Koefisien determinasi model pembelajaran inkuiri terbimbing berbasis lingkungan dapat menjelaskan karakter sebesar $12,2 \%$ dan sisanya $87,8 \%$ dijelaskan oleh faktor lain yang tidak diteliti. Hal ini diperkuat dengan penelitian yang dilakukan Sinaga (2014) yang menyatakan bahwa model pembelajaran inkuiri terbimbing berhasil mengembangkan karakter yaitu kerja keras, peduli lingkungan dan rasa ingin tahu. Karakter tersebut dapat mempengaruhi hasil investigasi pemecahan masalah yang dilakukan oleh siswa selama proses pembelajaran dengan inkuiri terbimbing.

Terdapat pengaruh model pembelajaran inkuiri terbimbing berbasis lingkungan terhadap pemahaman konsep dan karakter. Koefisien determinasi model pembelajaran inkuiri terbimbing berbasis lingkungan dapat menjelaskan pemahaman konsep dan karakter sebesar 95,2\% dan sisanya $4,8 \%$ dijelaskan oleh faktor lain yang tidak diteliti. Chiapetta dan Adams (dalam Jauhar, 2011:84-85), menyatakan bahwa inkuiri terbimbing sangat berperan dalam mengembangkan pemahaman fundamental mengenai konsep, fakta, prinsip, hukum dan teori serta pembentukan karakter positif terhadap sains.

\section{Penutup}

Berdasarkan analisis hasil penelitian yang telah dikemukakan, maka dapat disimpulkan bahwa: 1) terdapat pengaruh model pembelajaran inkuiri terbimbing berbasis lingkungan terhadap pemahaman konsep IPA pada siswa kelas V
SD Negeri Se-Kecamatan Brebes Kota sebesar $15 \%, 2$ ) terdapat pengaruh model pembelajaran inkuiri terbimbing berbasis lingkungan terhadap karakter pada siswa kelas V SD Negeri Se-Kecamatan Brebes Kota sebesar 12,2\%, 3) terdapat pengaruh model pembelajaran inkuiri terbimbing berbasis lingkungan terhadap pemahaman konsep IPA dan karakter pada siswa kelas V SD Negeri Se-Kecamatan Brebes Kota sebesar $95,2 \%$.

Sesuai dengan simpulan hasil penelitian, saran yang dapat disampaikan yaitu: 1) Bagi sekolah agar dapat meningkatkan kualitas pembelajaran dengan memberikan arahan dan pelatihan kepada guru dalam menerapkan model-model pembelajaran yang menarik bagi siswa, 2) Bagi guru menambah wawasan dan pengetahuannya tentang model-model pembelajaran yang lebih inovatif terutama model pembelajaran inkuiri terbimbing berbasis lingkungan, 3) Bagi siswa hendaknya dapat berperan aktif selama mengikuti KBM (Kegiatan Belajar Mengajar) yang dilakukan oleh guru dengan menerapkan berbagai model pembelajaran terutama model pembelajaran inkuiri terbimbing berbasis lingkungan, sehingga pemahaman konsep dan karakter siswa dapat meningkat.

\section{Daftar Pustaka}

Chen, C., T. \& She, H., C. (2013). The Effectiveness of Scientific. Inquiry With/Without Integration of Scientific Reasoning. International Journal of Science and Mathematics Education. Volume 2 (98-118).

\section{Damayanti, D. (2014). Panduan Implementasi Pendidikan Karakter di Sekolah. Yogyakarta: Araska.} $\begin{array}{crr}\text { Jauhar, M. (2011). Implementasi } & \text { PAIKEM } \\ \text { dari } & \text { Behavioristik } & \text { sampai }\end{array}$ 
Konstruktivistik. Jakarta: Prestasi Pustakaraya.

Putra, S., R. (2013). Desain Belajar Mengajar Kreatif Berbasis SAINS. Yogyakarta: DIVA Press.

Sinaga, G., E. (2014). Pengembangan Kombinasi Model Pembelajaran Berbasis Masalah dan Inkuiri Terbimbing pada Pembelajaran Kimia Larutan di SMA Kelas XI untuk Meningkatkan Hasil Belajar Kimia dan Karakter Siswa. Tesis. Medan: Universitas Negeri Medan.

Sugiyono. (2010). Metode Penelitian Pendidikan Pendekatan Kuantitatif, Kualitatif, dan $R \& D$. Bandung: Alfabeta.

Winnie, W., M. (2014). Representational Practices in Extra-Curricular Science Inquiry Projects: A Study With Asian Primary Pupils. International Journal of Science and Mathematics Education. Volume 1 (1-25). 